Eastern Illinois University

The Keep

October 2013

\title{
Engaging "Apolitical" Adolescents: Analyzing the Popularity and Educational Potential of Dystopian Literature Post-9/11
}

Melissa R. Ames

Eastern Illinois University, mames@eiu.edu

Follow this and additional works at: https://thekeep.eiu.edu/eng_fac

Part of the English Language and Literature Commons

\section{Recommended Citation}

Ames, Melissa R., "Engaging "Apolitical" Adolescents: Analyzing the Popularity and Educational Potential of Dystopian Literature Post-9/11" (2013). Faculty Research \& Creative Activity. 11.

https://thekeep.eiu.edu/eng_fac/11 inclusion in Faculty Research \& Creative Activity by an authorized administrator of The Keep. For more information, please contact tabruns@eiu.edu. 


\title{
Engaging “Apolitical” Adolescents: Analyzing the Popularity and Educational Potential of Dystopian Literature Post-9/11
}

\author{
Melissa Ames \\ Eastern Illinois University \\ mames@eiu.edu
}

\begin{abstract}
Although dystopian novels have been prevalent under the young adult banner for decades, their abundance and popularity post-9/11 is noteworthy. The $21^{\text {st }}$ century has found academics and laypersons alike discussing the supposed political apathy of young adults and teenagers of the Millennial Generation. However, despite this common complaint-and contrary to ample research that indicates that this age group has traditionally been uninterested in global politics-the reading preferences of this generation indicate that this label of "apolitical" may not be as fitting as some believe. In fact, the popularity of young adult dystopian literature, which is ripe with these political themes, suggests that this group is actually quite interested in these topics, although they often turn to the safe confines of fiction to wrestle with them. This article explores the potential educational uses of these young adult dystopias and argues that reading these texts may be a small step in the direction of engaging students in social justice issues and, perhaps, sparking more overt political action.
\end{abstract}

Although dystopian novels have been prevalent under the young adult (YA) banner for decades, their abundance and popularity post-9/11 is noteworthy. In the $21^{\text {st }}$ century academics and laypersons alike have discussed the supposed political apathy of young adults and teenagers of the Millennial Generation (1980-2000), ${ }^{1}$ causing national panic (at least around election time) about the future of democracy in the United States (Pew Research, 2010; Wishon, 2012). However, despite this common complaint-and contrary to ample research and poll data that indicates that this age group has traditionally been uninterested in current events, global politics, environmental concerns, and ethical debates involving scientific invention, human trafficking, and social equity - the reading preferences of this generation indicate that this label of "apolitical" may not be as fitting as some believe. In fact, the popularity of young adult dystopia, which is ripe with these political themes, suggests that this group is actually quite interested in these topics, although they often turn to the safe confines of fiction to wrestle with them.

This article brings current YA dystopian novels such as Feed (Anderson, 2002) and Little Brother (Doctorow, 2008), as well as series such as "The Hunger Games"

\footnotetext{
1 The term Millennial Generation is often used interchangeably with Generation Y, denoting the generation following Generation $X$. As with most generational categories, the exact start and end dates are often contested, with some claiming that the Millennial Generation starts with those born in 1977 and others arguing that it does not start until the mid-1980s. Whatever the start date, most estimates have the generation ending at 2000 (with the change of the new millennium) or 2001 (with the changes that accompany 9/11).
}

(C) 2013 The University of North Carolina Press 
(Collins, 2008, 2009, 2010), "Uglies" (Westerfield 2005, 2006, 2007), and "Matched" (Condie, 2010, 2011), into conversation with various ancestor texts. Analyzing the socio-political commentary present within this popular body of literature provides insights into the concerns this generation may have for the future-concerns which are not always being expressed via traditional democratic processes. This article explores the reasons why this subgenre has recently become so popular with teen audiences, especially in light of the social critiques this group receives, and argues that these reading practices indicate that today's youth are often portrayed unjustly. Specifically, this article argues that the post-9/11 climate has contributed to the popularity of these YA dystopias as they present fictional fear-based scenarios that align with contemporary cultural concerns. While these texts do not always serve as direct allegories for $9 / 11$, or draw attention to specifically post-9/11 concerns (although many do), they all provide social commentary that is relevant to society today. The eager consumption of this social commentary by youth is important to consider. The popularity of these novels may suggest that young adults do not warrant being classified as politically disengaged. Because much of the research concerning this generation's political involvement and civic illiteracy is convincing, critics might argue that this political engagement via the page is not enough to celebrate. However, this article explores the potential educational uses of these YA dystopias and contends that reading these texts may be a small step in the direction of engaging students in social justice issues and, perhaps, sparking more overt political action.

\section{Analyzing the Audience: Research on Civic Responsibility and Civic Literacy Among Teens}

The justification for labeling this generation as apathetic or apolitical usually stems from research related to civic responsibility (as indicated through studies on voter turnout) and knowledge of current affairs. In a typical presidential election it is often "a struggle to get half of the country to vote" and the youngest voters have traditionally been the least likely to make it to the voting booth (Wolk, 2009, p. 666). While recent studies indicated that this may eventually not be the case, as the youth share of the total vote has increased consistently throughout the past four presidential elections: 2000, 14.3\%; 2004, 16.0\%; 2008, 17.1\%; 2012, 19\% (Richer, 2012; Kingkade, 2012), some still remain skeptical about civic engagement among the youth population. Although recent presidential elections saw an increase in voter turnout among this age group - up to approximately $52 \%$ - a recent survey of 3,000 college students reported that $20 \%$ claimed they "would sell their next vote for an iPod and half said that for one million dollars they would give up their right to vote forever" (Wolk, 2009, p. 666).

But, as Wolk (2009) noted, the "low voter turnout may be the least of the civic problems"; he claimed the larger problem is civic illiteracy, which he called an "epidemic" plaguing the United States (p. 667). A 2007 survey conducted by the Pew Research Center illustrated this point. The survey asked 18- to 29-year-olds a dozen questions on well-publicized current events. The result? The average respondent only answered 5.5 correct (Wolk, 2009). Half of the participants did not know the name of the Speaker of the House, the president of Russia, or how many American troops had been killed in Iraq (Pew Research Center, 2007). Bauerlein (2009), author of The Dumbest Generation: How the Digital Age Stupefies Young Americans and Jeopardizes Our Future, Or, Don't Trust Anyone Under 30, reported that in similar studies, while 64 percent of young adults knew the name of the latest American Idol, "only one-third knew which party controlled the state legislature, and only 40 percent knew which party controlled Congress” (p. 19). Furthermore, 
"in a 2003 survey on the First Amendment commissioned by the Foundation for Individual Rights in Education, only one in 50 college students named the first right guaranteed in the amendment, and one out of four did not know any freedom protected by it" (Bauerlein, 2009, p. 19). Although a 2004 report conducted by the U.S. Department of Education indicated that 47 percent of high school seniors believed it is "very important" to be an active and informed citizen, only 26 percent of high school seniors scored "proficient" or "advanced" on the national civics exam (Bauerlein, 2009, p. 35). These studies exhibit a general lack of knowledge of political affairs.

Often overlooked in discussions concerning this data are the reasons why young people today are demonstrating such a knowledge deficiency. Barnhurst (1998), a media researcher, argued that young people today feel disconnected from traditional sources of political information such as the news. Similarly, a 1999 study conducted by Northwestern University's School of Journalism found that $69 \%$ of young people ages 15 to 24 believed that although their "generation has an important voice," it goes unheard (Bauerlein, 2009, p. 185). More recent scholarship shows that this mindset still prevails. Mindich's (2005) Tuned Out: Why Americans Under 40 Don't Follow the News featured hundreds of interviews with young adults who claimed that the political process is morally bankrupt and completely insulated from public pressure. Therefore, they tuned it out.

Although all of this data paints a bleak picture, some recent studies offer up hope that civic involvement may actually be rising, albeit slowly, among all populations in general and young adults in particular. Putnam's original study reported that by the late 1990s, an increase in youth volunteer work was present that had the potential to spark broader generational engagement (Sander \& Putnam, 2010, p. 10). Published only months before 9/11, Putnam's (2001) words toward the close of his book can now be read with disheartened irony. He suggested that the task of sparking greater engagement "would be eased by a palpable national crisis, like war or depression or natural disaster, but for better and for worse... America at the dawn of the new century [appeared to face] no such galvanizing crisis” (p. 402). Of course, he was wrong.

In a much-needed follow-up piece, Sander and Putnam (2010) analyzed the effects the 9/11 crisis, which Putnam could not foresee, had on civic engagement. They determined that it seemed "to have strengthened the civic conscience of young people in the United States" (p. 10). They reported that, "young collegians' interest in politics has rapidly increased" in the years following 9/11 after three decades of steady decline (p. 11). In the period from 1967 to 2000, the share of college freshmen who said that they had " 'discussed politics' in the previous twelve months dropped from 27 to 16 percent; since 2001, it has more than doubled and is now at an all-time high of 36 percent" (p. 11). Sander and Putnam (2010) also stated:

First-year college students also evince a long-term decline and then post-2001 rise in interest in "keeping up to date with political affairs." Surveys of high school seniors show a similar and simultaneous decline and then rise in civic engagement. Moreover, between 2000 and 2008, voting rates rose more than three times faster for Americans under age 29 than they did for Americans over 30. (p. 11-12)

According to Sander and Putnam (2010), "the turning point in 2001 is unmistakable" (p. 12).

Besides the national tragedy, "some credit Internet-based social networking for bolstering youthful interest in politics and community life," but, as Sander and Putnam (2010) pointed out, "the advent of the well-known social-networking sites 
Facebook (2004) and Twitter (2006) occurred years after the initial upturn in civic engagement by young people," so they cannot take full credit for such a change in tides (p. 12).

However, such social-networking sites certainly seem to be providing youth with more opportunities to engage in political discourse-critiquing media coverage, posting personal commentaries, and following important social movements. Although Sander and Putnam's (2010) study was late enough to have witnessed the 2008 election, which proved that young adults were more politically engaged (as indicated by voting statistics at least), what they were not able to report was even more overt political action, such as the Occupy Wall Street protests. This movement, which began on September 17, 2011, promoted its protests through the social networking sites most frequented by youth in the U.S. As a result, young people made up the majority of the participants (Captain, 2011; Askin, 2012).

These assertions about young adults suggest that this new generation-inspired by 9/11 and further invigorated by new technological platforms-is experiencing rejuvenation in terms of civic involvement. This could account for their sudden interest in young adult literature that caters to such mindsets.

\section{The Current Popularity of Young Adult Dystopian Novels}

Previous scholars have noted that "contemporary dystopian fiction, and the utopian fiction it derives from, often includes a critique of a 'postmodern,' advanced technological society gone awry” and calls for social change (Zipes, 2003, p. ix). These kinds of texts "mirror and criticize reality, forcing readers to consider reality, ironically at the same time as they are escaping from it" (Hintz \& Ostry, 2003, p. 6). Such narratives play upon deep, unresolvable fears from "reality," exaggerating (and sometimes solving) them in fictional scenarios. In the case of young adult dystopia, it is the young people-willing or not-who must confront these fears and ultimately solve the problems that spawn them. Despite their dark content, "dystopian novels... have apparently now surpassed the vampire and fantasy genres in the young adult fiction market" (Hall \& Slade, 2011, para. 1). With more than 36.5 million copies sold in the United States alone (Lee, 2012), Suzanne Collins's “The Hunger Games" series—often credited for furthering the YA dystopia trend (Rhor, 2012) recently surprised many by surpassing the sales figures for Rowling's popular "Harry Potter" series (Gaudiosi, 2012). The success of her books, and the YA dystopias following them, indicate that this is more than just a mere marketing achievement.

The questions remain: Why are these young adult dystopias so popular? Why are they so popular at this exact moment? Julie Bertagna (2011), a young adult author, asked, "Have teenagers, fed on an everyday diet of terror-war, recession, floods, hurricanes, earthquakes, swine flu, become disaster junkies?” (p. 1). Goodnow (2008) said the genre is popular because it "mirrors a world beset by some of the most frightening problems in recent memory, from climate change to terrorism and the shredding of privacy and free will," making it "the zeitgeist of the times" (p. 1). While all of these are convincing rationales for the popularity of the genre, this article makes the case that the socio-political climate that has emerged post-9/11 has greatly contributed to the mass consumption of these texts.

\section{YA Dystopia as Part of a Larger Post-9/11 Phenomenon and Cultural Coping Mechanism}

In many ways it is more useful to study the surging popularity of YA dystopia alongside similar trends: post-apocalyptic narratives (be they in the form of print fiction, film, television, or video games) that share similar characteristics; zombie 
and vampire storylines with their fear-based "us versus them" binaries; and horror films that encompass the above subcategories, to name a few. The fact that the grim apocalyptic imagery present in mainstream texts has filtered down into young adult literature is quite telling. Rawls (2012) claimed that, "the young are often an important gauge of just how entrenched various themes may be" (para. 10). Speaking specifically of Collins's (2008) The Hunger Games, she asked: "Could a post-apocalyptic story about poor children chosen by lottery to kill one another have become a blockbuster hit with the tween crowd at any other moment in American history, or is The Hunger Games a strangely decade-specific phenomenon?" (Rawls, 2012, para.10). Other scholars have made similar claims-that such trends are decade-specific or linked in some way to the aftermath of 9/11. Studying the renewed popularity of horror films in the years following 9/11, Soloff (2006) discussed how filmmakers expressed "post-9/11 anxieties through metaphor," allowing cinema to become a "therapeutic catharsis for the nation's newfound fears" (para. 1). Examining the recent resurgence of zombie narratives in his article, "Are Zombies the Guilty Conscience of Post-9/11 America?" Nixon (2011) suggested "that the zombie renaissance" represents American's reactions "to 9/11 and the mess" the government made of global relations ever since the attacks (para. 5).

All of these arguments seem quite sound. After all, to claim that the national tragedy of $9 / 11$ has been a defining moment in the first decade of the $21^{\text {st }}$ century for the United States is not profound, nor is the statement that it directly and indirectly influenced the cultural production within U.S. society throughout these years. In the decade following the attacks on the World Trade Center and the Pentagon, cultural products have been sites for interrogating and remediating the trauma that 9/11 caused for the citizens of a country that believed itself to be untouchable. Redfield (2007) stated:

That the attacks inflicted a shock of historical scale seems clear, but the shape and scope of this wound is not... If we try to conceive of trauma on a cultural level things become more ambiguous... [The attacks] were not of a societythreatening scale... and the literal damage they did to the military and commercial orders symbolized by the Pentagon and the World Trade center was miniscule; it is of course as symbolic acts of violence that they claim culturally traumatic status. (p. 56)

He continued to analyze the common effects of trauma and the coping process that individuals usually go through: "trauma involves blockage: an inability to mourn, to move from repetition to working-through." (Redfield, 2007, p. 56). He argued that, "wherever one looks in 9/11 discourse, trauma and the warding-off of trauma blur into each other, as the event disappears into its own mediation" (p. 57).

I propose that a very similar process is at work in the apocalyptic narratives that proliferated after 9/11. Through their mediation of fictionalized scenarios, they present trauma in order to do away with it, hence becoming a sort of emotional security blanket for individuals existing in an unstable post-9/11 world. In terms of YA dystopias in particular, the fact that teenagers are eagerly consuming these themes suggests that they are seeking a safe space to wrestle with, and perhaps displace, the fears they play upon-fears that are set and, not unimportantly, resolved amidst the comfortable narrative threads of young adult narratives: coming of age rituals, identity struggles, romantic love triangles, and so forth.

To be clear, it may not be the events of 9/11 themselves that are responsible for the fears that adolescent readers have today, especially since for many the national 
tragedy is an event that barely lingers in their actual memories due to their young ages. Rather, it is the post-9/11 climate that has instilled and perpetuated a climate of fear, which they have become a part of (e.g. the rhetoric of the Bush administration; media pundits with their endless prophetic predictions of future disasters). Teens are now entrenched in the culture of the 24-hour news networks and connected to social media, which constantly expose them to depictions of terror, extremism, and violence. Arguably, the cultural "mood" created by the abovementioned factors influences their literary choices. Although teens may not be conscious of fears related to $9 / 11$, they are a part of the social and political climate-a climate that provides a ripe context for these dystopian texts.

However, it is important to note that not all scholars agree that this trend is necessarily the result of $9 / 11$. Some suggest instead that the popularity of these texts may stem from something other than the current sociopolitical climate; it may be a ripple effect from the prior decades. The majority of the authors writing young adult fiction today lived through the Reagan era, the 1980s Cold War scare, and the broadcast of The Day After (1983), which was terrifying for some. As high school students they were taught a variety of texts concerned with misery and social control, such as 1984, Fahrenheit 451, Brave New World, Flowers for Algernon, and Lord of the Flies (Hall \& Slate, 2011). The dystopian literature of the 1980s was preoccupied with mass destruction, atomic bombs, and apocalyptic outcomes. But, as Hall and Slade (2011) noted, this generation did not face such a future; they did not die, but instead "just ended up with mortgages, subscriptions to the New Yorker, and a grinding sense of regret. And now apparently they are writing, publishing, and promoting postapocalyptic and dystopian fiction for young people at an unprecedented rate" (para. 7). Therefore, it may very well be that this current upswing in YA dystopia should be attributed to the authors themselves, for it is just as likely that it is their political concerns that are projected upon the pages more so than those of their readers. In terms of crafting the market for these texts, it may be a mistake to assign the impetus to the young adults themselves, but instead to the authors who framed the texts within these themes, or even the publishers who were eager to push texts that capitalized on post-9/11 concerns. Regardless of who or what deserves credit for rejuvenating this profitable subset of young adult literature, teenagers are reading these texts and are, therefore, sustaining the market. Their enthusiastic engagement with these novels calls for reevaluating the claims that this generation is apathetic when it comes to national and global issues.

\section{Historicizing the Trend: Young Adult Literature's Dystopian Traditions}

It would be misleading to present political focus as entirely new in YA literature. Dystopian themes and political concerns have filled the pages of YA novels since their beginnings. Various recurrent motifs can easily be traced throughout the decades proving this point. For example, many novels have been founded on the premise of technology leading to society's downfall: Schlee's (1979) The Vandal, Westall's (1983) Futuretrack 5, Staig's (1989) The Glimpses, Kelleher's (1995) Parkland, and Haddix's (2000) Turnabout. Others have focused on dystopic scenarios resulting from human-caused environmental disasters: Hoover's (1973) Children of Morrow, Anderson's (1977) In the Keep of Time, Gee's (1982) The Halfmen of O, Streiber's (1985) Wolf of Shadows, Park's (1986) My Sister, Sif, Macdonald's (1988) The Lake at the End of the World, McNaughton's (2000) The Secret Under My Skin, and Cooper's (2001) Green Boy. And still others have featured versions of totalitarian societies where quests for complete control or human perfection have led to dystopian conditions: Wyndam's (1955) The Chrysalids, Parenteau's 
(1979) The Talking Coffins of Cryo-City, West and MacLean's (1979) Dark Wing, Sargent's (1980) Watchstar, Prince's (1986) The Others, Thomas's (1988) Cityscape, Richemont's (1990) The Game, Lowry's (1993) The Giver, Haddix's (2000) Among the Hidden, and Lowry's (2000) Gathering Blue. ${ }^{2}$ This list is, of course, far from exclusive, but this mere sampling indicates that the popular young adult dystopias of present have a long line of ancestor texts that precede them.

The most popular young adult dystopias of late have tapped into many of the abovementioned themes but have done so in ways that speak to the current cultural moment. For example, the majority of them explore the effects of technologically driven, surveillance-ridden societies. These novels often allude subtly (or not-sosubtly) to the culture of narcissism inspired by social networking, the consumerist nature of the media-saturated world, or the infringements of personal liberties in the United States after passage of The Patriot Act.

At the core of many of the most popular YA novels published in the last decade is a government that seeks to quell rebellious impulses. This is accomplished, for example, in Feed (2002) and Uglies (2005) via distraction and in The Hunger Games (2008) and Little Brother (2008) through direct punishment. Although this could be seen as a commentary on current times-an era that has seen a wave of resurrected conservatism and conformity-it also is very much a staple of young adult literature more generally. Dystopian narratives play well to teenage audiences because they serve as powerful metaphors for their current developmental stage (Hintz \& Ostry, 2003). Hintz and Ostry (2003) explained, during "adolescence, authority appears oppressive, and perhaps no one feels more under surveillance than the average teenager" (p. 9-10). Westerfeld, the author of the "Uglies" series, explained the genre's fit for adolescence, describing high school as being a dystopia of sorts: "Bound by the rules of teachers, parents and society, with little power over your own existence, life as a teenager can feel like living in an authoritarian state" (as cited in Bertagna, 2011, p. 2). Therefore, it seems like a natural progression for this theme of autonomy to get taken up in young adult texts. A short discussion of recent YA successes (analyzed in reverse chronological order in terms of their publication date) showcases how these dystopian tales have evolved throughout the last decade and reinforced certain motifs.

\section{Young Adult Literature Today: Critiquing the Cultural Moment}

\section{Matched (First Novel of Series)}

One of the most recent dystopian young adult series is Condie's (2010) Matched. Condie's opening novel was named one of the Best Children's Books of 2010 by Publishers Weekly and it made its way into The New York Times' list of the top 10 best-selling children's books (Fulton, 2011). The series depicts a society that relies on calculated planning "where each of life's stages-from marriage at age 21 to death on or before age 80-is decided in advance for optimal results" (Fulton, 2011, p. 2). Although Condie's texts focus on how life in this civilization is planned down to the minutia (even citizens' meals are planned in order to ensure optimal nutrition), the primary storyline focuses on the romantic triangle that results when the main character, Cassia, is accidentally "matched" (paired as a life mate) with two different boys.

\footnotetext{
2 For more information on the above listed texts, and many others, see Hintz, Ostry, Sambell, and Totaro's (2003) very thorough "Annotated Bibliography of Utopian and Dystopian Writing for Children and Young Adults” in Utopian and Dystopian Writing for Children and Young Adults.
} 
Part of the novel's cultural critique comes into play when Condie described the ways in which the society had decided to preserve cultural and historical artifacts: in the fashion of an exaggerated "throw away" culture, record keeping and personal preserves were virtually eliminated and only things of value (as decided by a government committee) were saved. Morris (2011) argued that, "Condie bottles up all the hand-wringing over information overload" and filters it through the current cultural obsession with top-10 lists, dramatizing "our messy, disjointed, perhaps even schizophrenic, relationship to cultural products” (para. 4).

One particular collection of cultural products that received additional scrutiny in the novel was technological gadgets. Cassia alluded to a previous era that was overly dependent on technology, which allowed the novel to unveil yet another cultural critique about our current times: "You never know when technology might fail... [and] specialization keeps people from becoming overwhelmed. We don't need to understand everything" (Condie, 2010, p. 31). This quote could be interpreted as housing more than just a commentary on our overreliance on technology and its resulting information overload. The Society's belief that information should be specialized and restricted to the few, that citizens "don't need to understand everything" could be a nod toward the post-9/11 cultural climate where citizens are not expected to understand everything, especially in regard to how their country protects them in face of terrorist threats. More explicit may be the novel's link to the post-9/11 surveillance culture. The Society's extensive means of control reflects contemporary fears of being constantly monitored (e.g., The Patriot Act, Transportation Security Administration security protocol). This motif of surveillance, common to the YA dystopian genre, becomes amplified in many publications post-9/11.

\section{The Hunger Games (First Novel of Series)}

Hall and Slade (2011) argued that, "The Hunger Games series is probably the most visible example of the dystopian trend" (para. 9). As previously discussed, millions of copies have been sold, and it is now a movie franchise. It has also garnered much critical acclaim as a bestseller according to The New York Times, USA Today, The Wall Street Journal, and Publishers Weekly. It was in the American Library Association's top ten best books for young adults; it won the "Best Indie Young Adult Buzz Book Honor," the 2008 Cybil Award in the category of Fantasy and Science Fiction, and the 2009 Children's Choice Book Award, as well as many other accolades.

Collins's trilogy can be read as critiquing many different aspects of contemporary society, most obviously our entertainment choices. As Goodnow (2008) noted, "Suzanne Collins holds a warped, funhouse mirror up to the excesses of reality TV” (para 8). Granger (2010) read the series as critiquing "our addiction to television and its soul corrosive influences" (p. 1). Interviews with Collins, who shared "that her inspiration for the story came from channel surfing and being impressed by the televised images of the war in Iraq and the reality television shows," confirmed Granger's reading. However, the focus on surveillance, key to critiquing the reality television phenomena, is also rather common among young adult dystopia as the theme speaks to "teenagers who are temporarily trapped in the high school panopticon" (Hall \& Slate, 2011, para. 22).

The series offers critiques in other areas as well. It can be read as an allegory for the state of both capitalism and education today as, like the competitors selected from various fictional districts, "some children start with advantages due to wealth. Other children-the unprepared ones, the ordinary ones-die unceremoniously, as the children with advantages temporarily band together to kill everyone else first 
before turning on each other" (Hall \& Slate, 2011, para. 14). Prinzi (2010) drew attention to the "ongoing commentary on poverty in the books" (para. 8). The clearest moment of class commentary comes through the scene in which Katniss and Gale delivered strawberries to the Mayor's house on the day of the Reaping Ceremony and encountered his daughter Madge, who was seemingly unaware of how her wealth inadvertently protected her from the likelihood of being selected for the participation in the Hunger Games. Reflecting on why this meeting infuriated Gale, Katniss mused:

You can see why someone like Madge, who has never been at risk of needing a tessera, can set him off. The chance of her name being drawn is very slim compare to those of us who live in the Seam. Not impossible, but slim. And even though the rules were set up by the Capitol, not the districts, certainly not Madge's family, it's hard not to resent those who don't have to sign up for the tesserae. (Collins, 2008, p. 13)

The poorer residents of District 12 (those living in "the Seam") were often forced to purchase additional food supplies by adding to the number of times their names appeared in the candidate pool for the games. This was not the only way that the poor were at a disadvantage. The districts were numbered in the book according to their overall wealth. District 1, for example, was among the richest districts outside the Capitol and District 12 was among the poorest. The Game favored the rich in that the wealthier districts could afford to train some of their young to compete in the games, in hopes that they would win the honor and supply their district with the rewards that accompany the victory. Aware of this, Katniss contemplated the impossibility of beating out one of these trained "Career" tributes in the games: "I can't win... The competition will be far beyond my abilities. ... Boys who are two to three times my size. Girls who know twenty different ways to kill you with a knife” (p.36).

Collins highlighted other moments of economic imbalance in scenes that dealt not with the games in particular but with their main spectators: the residents of the Capitol. The Capitol was depicted as a place of rich and ridiculous abundance, and the citizens themselves embodied this aura of excess through their obsessions with frivolous fashion fads. The contrast between the appearance of these individuals and the poor inhabitants from the districts is noteworthy:

They do surgery in the Capitol, to make people appear younger and thinner. In District 12, looking old is something of an achievement since so many people die early. You see an elder person, you want to congratulate them on their longevity, ask the secret of survival. A plump person is envied because they aren't scraping by like the majority of us. But here it is different. Wrinkles aren't desirable. A round belly isn't a sign of success. (pp.124-125)

While Collins's critique of social inequality can certainly be read as a critique of our current times-the motto of the Occupy Wall Street movement, "We are the 99\%," would certainly apply to those residing in the outer districts of Panemthere were moments of social commentary that seem to point even more specifically to this historical moment.

Prinzi (2010) noted how the series draws attention to the "abuse of power during wartime" (para. 8). Some of these moments seem to resonate in the post-9/11 era where individual freedoms have been threatened through the passage of The Patriot Act. The novel's focus on being watched certainly could be read as alluding to our current culture of forced surveillance, but the moments where Katniss reflected on 
the dangers of speaking out against the Capitol could also be read as a commentary on the ease in which an American citizen today could be reclassified as an enemy of the state.

\section{Little Brother (Novel)}

Like "The Hunger Games" series, Little Brother (Doctorow, 2008) was well received, earning a long stay on The New York Times Bestseller List and winning awards such as the 2009 John W. Campbell Memorial Award, the 2009 Prometheus Award, and the 2009 White Pine Award. VanderMeer (2008) described Doctorow's novel as "Orwell for the teen set" (para. 4) and Goodnow (2008) agreed, arguing that "the post- 9/11 tension between security and liberty inspires classic Orwellian themes... [in this novel] about a teen who is wrongfully detained and tortured by the Department of Homeland Security (DHS)" (para. 13). The allusion to Orwell's 1984 was by no means subtle, as the main character, who used his hacking skills to sabotage the corrupt DHS, was known in cyberspace through his handle "wIn5ton," which is, of course, pronounced "Winston," the protagonist of Orwell's classic dystopia (Goodnow, 2008, para. 8).

Although, like the other books discussed, there was a minor love story (and love triangle of sorts) lurking in the pages of this novel, it played a relatively small role in the plot. In fact, this text, of the contemporary YA dystopias discussed here, was the most overt in its social critique. It was clearly a critique of the Patriot Act and other governmental abuses in the name of national security post-9/11. This critique is obvious from the moment Marcus and his friends were apprehended simply because they were in close proximity to the site of the explosion that destroyed the Bay Bridge in San Francisco during a terrorist attack. Readers slowly come to the realization, along with the main character, that the teens were held by the Department of Homeland Security and not by foreign terrorists. This scene not only provided a commentary on abuses of power in the name of war, but also on the stereotypical way in which terrorists have been portrayed via mainstream media:

I didn't know what a terrorist looked like, though TV shows had done their best to convince me that they were brown Arabs with big beards and knit caps and loose cotton dresses that hung down to their ankles. Not so our captors. They could have been halftime-show cheerleaders on the Super Bowl. They looked American in a way I couldn't exactly define. Good jawlines, short, neat haircuts that weren't quite military. They came in white and brown, male and female, and smiled freely at one another as they sat down at the other end of the truck, joking and drinking coffee out of go-cups. They weren't Ay-rabs from Afghanistan: they looked like tourists from Nebraska. (Doctorow, 2008, p. 43)

All of the scenes with the chief interrogator, whom Marcus refers to as "Severe Haircut Lady," pointed toward the new post-9/11 mindset that, in the name of national security, one could now be considered guilty until proven innocent:

You're under the mistaken impression that you've been picked up by the police for a crime. You need to get past that. You are being detained as a potential enemy combatant by the government of the United States. If I were you, I'd be thinking very hard about how to convince us that you are not an enemy ... combatant. Very hard. Because there are dark holes that enemy combatants can disappear into, very dark deep hoes, holes where you can just vanish. Forever. (Doctorow, 2008, p. 49)

Although the text is clearly against these new practices, Doctorow created characters that justified these acts to some degree. One of those characters was Marcus's father 
who made the claim, "The world isn't the same place it was last week" (Doctorow, 2008, p. 109), which is similar to those made concerning 9/11-that the attacks on the World Trade Center and Pentagon changed everything.

The realism of this text differs from that of the others discussed in this article, as does its almost overt call to action. Unlike most young adult novels, Doctorow's text reads as if he was purposely attempting to spark political action in his teen readers. Marcus's final speech at the close of the novel supports this analysis:

They betrayed our trust. The election is four months away. That's a lot of time. Enough for you to go out and find five of your neighbors - five people who've given up on voting because their choice is 'none of the above' talk to your neighbors. Make them promise to vote. Make them promise to take the country back from the tortures and thugs. The people who laughed at my friends as they lay fresh in their graves at the bottom of the harbor. Make them promise to talk to their neighbors. Most of us choose none of the above. It's not working. You have to choose - choose freedom. My name is Marcus Yallow. I was tortured by my country, but I still love it here. I'm seventeen years old. I want to grow up in a free country. I want to live in a free country. (Doctorow, 2008, p. 363)

Considering the very clear post-9/11 commentary running throughout the novelwith multiple references to the fictionalized Patriot Act II-the corrupt government referred to in Marcus's idealistic and somewhat didactic speech could be read as a hyperbolic stand-in for the Bush Administration, the governmental body that would have been in power as Doctorow was crafting this text. ${ }^{3}$

\section{Uglies (First Novel of Series)}

Named in the Best Books for Young Adult List compiled by the American Library Association in 2006, Westerfeld's (2005) "Uglies" series focused on a post-apocalyptic society where cosmetic surgery was mandated at age sixteen in order to rid citizens of physical differences, such as race and beauty, that in the past resulted in inequality and even war. Accompanying this physical transformation, unknown to those who experience it, was a mental one wherein the participants' brains were altered so that they remained in a permanent state of "bubbly" (ignorant) bliss. The original trilogy, and to some extent the follow-up book, Extras (Westerfeld, 2007), focused on Tally Youngblood, the young protagonist who ultimately dismantled this societal system.

The central commentary of these books centered on the current surge in cosmetic surgery and offers "an impetus for an important dialogue about beauty standards and our culture's” captivation with them (Scott \& Dragoo, 2011, p. 11). Westerfeld created a protagonist who initially had bought into the cultural mindset that physical perfection is the key to happiness. Through exaggeration, his fictional world draws attention to our own time period's problematic focus on beauty, while still allowing us to seem less drastic in comparison. Consider this scene where Tally stumbled upon celebrity magazines from the Rusty Era (the phrase used to demark our contemporary times):

She'd never seen so many wildly different faces before. Mouths and eyes and noses of every imaginable shape, all combined insanely on people of every age.

3 This type of contemporary cultural critique can also be seen in the sequel to this novel, Homeland (Doctorow, 2013) where the narrative focuses on an economic collapse related to both corporate and political corruption. 
And the bodies. Some were grotesquely fat, or weirdly over muscled, or uncomfortably thin, and almost all of them had wrong, ugly proportions. But instead of being ashamed of their deformities, the people were laughing and kissing and posing, as if all the pictures had been taken at some huge party. (Westerfeld, 2005, p. 197)

Although this scene highlighted one's ability to achieve happiness and success in the current world despite physical imperfections, other scenes pointed toward the detrimental consequences of our contemporary beauty standards. While looking at a picture of a model in a magazine, Tally noted, "The woman looked like she was starving, her ribs thrusting out from her sides, her legs so thin [she] wondered how they didn't snap under her weight. Her elbows and pelvic bones looked sharp as needles" (p. 199). Westerfeld also included an allusion to the current epidemic of eating disorders plaguing the United States: "Tally remembered that a lot of people, especially young girls, became so ashamed at being fat they stopped eating. They'd lose weight so quickly, and some would get stuck and would keep losing weight... No one got this disease anymore since everyone knew at sixteen they'd turn beautiful" (pp. 199-200). Through various debates in the first half of the novel between Tally and characters against the mandatory plastic surgery, Westerfeld drove home his underlying message that beauty is nothing but a social construct: "It's a trick, Tally. You've only seen pretty faces your whole life. Your parents, your teachers, everyone over sixteen. But you weren't born expecting that kind of beauty in everyone, all the time. You just got programmed into thinking anything else is ugly" (p. 82).

This series also critiqued our culture's "voyeuristic obsession with celebrity" and tendency to link personal identity to material products (Goodnow, 2008, para. 22). This latter issue is particularly directed toward teenagers who "are particularly subject to the influence of consumerism... because consumer goods are among the few ways that [they] can establish status boundaries" (Detora , 2006, p. 28). It is the companion book, Extras, that most clearly addressed the culture of narcissism being driven by celebrity focus and, perhaps, social networking. This final book in the series showcased a society where awards and material goods were allotted to individuals based on their "face rank"-their popularity and importance as measured by the amount of attention they received from others, as their profiles and feeds were followed and commented upon.

Although less central, the series also addressed other concerns that often surface in dystopian texts: environmental ruin, overpopulation, social inequality, and so forth. The environmental concern especially is spelled out at the close of the original trilogy in the protagonist's "manifesto":

Whenever you push too far into the wild, we'll be here willing, ready to push back. Remember us every time you decide to dig a new foundation, dam a river, or cut down a tree. Worry about us. However hungry the human race becomes now that the pretties are waking up, the wild still has teeth... We'll be out here somewhere - watching. Ready to remind you the price the Rusties paid for goingtoo far... Be careful with the world, or next time we meet, it might get ugly. (Westerfeld, 2005, pp. 371-372).

Tally's warning closed the series with a healthy dose of didacticism and hope, two complementary prerequisites often found in young adult dystopia.

While the "Uglies" series did not overtly draw attention to societal concerns directly related to the $9 / 11$ terrorist attacks in ways that the texts published later 
in the decade, they did attend to equally important social issues. Since the popularity of this series has increased with the passage of time-as evidenced by its forthcoming film adaptation-these books highlighted the fact that the dystopian genre continues to prosper in the post-9/11 era, exposing teen readers to an array of cultural critiques.

\section{Feed (Novel)}

Anderson's (2002) Feed utilized the backdrop of a post-apocalyptic world to critique the effects of advanced technology on humankind and the environment. Recognized by the Boston Globe-Horn Book Award, the Riverbank Review of Children's Books, and the National Book Award, among others, Feed presented a vision of an earth all but destroyed by humans. In this technology-saturated society, the majority of the population had computerized information feeds implanted in their brains. These feeds constantly brought them endless streams of information, usually in the form of advertising for consumer products. This technology allowed for instantaneous communication and internal abbreviated dialogues (much like instant messaging) among people, so that traditional face-to-face conversation was almost no longer needed.

However, the increased reliance on technology came with a consequence-a decrease in intelligence. The characters' slang-ridden dialogue helped to underscore this while their actual statements often demonstrated their ignorance. One example would be a character arguing that his face was an organ because "it's alive" (Anderson, 2002, p. 7). The notion that people could not think independently or retain information on their own in the age of the feeds was highlighted early on in the story when a hacking incident caused the main character, Titus, and his friends to have to be without their feeds for a period of time while they healed:

I don't know when they first had feeds. Like, maybe, fifty or a hundred years ago. Before that, they had to use their hands and their eyes. Computers were all outside the body. They carried them around outside of them, in their hands, like if you carried your lungs in a briefcase and opened it to breathe. (p. 47)

Anderson complicated this critique by placing the blame not with technology alone but with those who benefit from it: big business. He created a world where the education system had been co-opted by capitalism and this had contributed to the declining intellect of citizens. Titus's reflections on the function of school in this world showcased this well:

School is not so bad now, not like back when my grandparents were kids, when the schools were run by the government... Back then it was big boring, and all the kids were meg null, because they didn't learn anything useful... Now that School is run by the corporations, it's pretty brag, because it teaches us how the world can be used, like mainly how to use our feeds... They care about America's future. When no one was going to pay for the public schools anymore and they were like filled with guns and drugs and English teachers who were really pimps and stuff, some of the big media congloms got together and gave all this money and bought the schools so that all of them could have computers and pizza... And now we do stuff in classes about how to work technology and how to find bargains and what's the best way to get a job and how to decorate our bedroom. (pp. 109-110)

In an interview Anderson noted that besides serving as a cautionary tale about the misuse of technology, his novel was intended to scrutinize the current culture 
of instant gratification, aspects of herd psychology, and individuals' refusal to tackle serious societal problems (Blasingame, 2003).

Unlike the YA books discussed previously, Feed did not feature a protagonist who raged against his society's problems to save the day, nor did it end with the typical seed of hope that most young adult dystopias contain. In her review of the novel, Devereaux (2002) noted this deviation from the classic YA formula. Most authors set up dystopian worlds in order for their characters to have a hand in dismantling them; this is not the case in Feed (Devereaux, 2002). The main character was an anomaly of sorts compared to the main characters in most young adult dystopian novels as he was not cast as a hero. ${ }^{4}$ Although his love interest in the book did play this role to some extent (albeit unsuccessfully), Titus's characterization was in line with the current belief that teenagers are unwilling to tackle cultural problems. In fact, Feed is one of the few YA books that crafts a main character who aligns with the research on young adults today regarding civic illiteracy, political disinterest, etc. By placing a character like Titus into the typical worst-case scenario setting of a YA dystopia, the novel speaks to the concerns older adults have for the future of the country if this so-called apathetic generation remains civically disengaged despite escalating national and global problems. In some ways, Anderson's (2002) harsh depiction of young adults, while problematic to some degree, is the most provocative. In purposefully deviating from the classic "teen saves world" narrative structure, he created a space for the young adults reading his novel to ponder the potential effects of political apathy. If teen readers are frustrated by, or disapprove of, Titus's lack of action, perhaps this text has the potential to spark self-reflection and generational critique in ways that the previously discussed texts do not.

\section{The Power of the Page: What do Young Adults $D O$ with these Narratives?}

Many feel that young adult dystopias are written by authors in the hope that their messages will spark action amongst their teenage readers. But does this happen? Do young adults pick up on this social commentary and incorporate it into their own worldviews? Hall and Slade (2011) suggested that they might not:

It is easy to assume that young readers would follow the lead of adult authors and commentators in reading these books as future-oriented social commentary. But adult fears for an uncertain future can become a different tool in younger hands. The ways that young people read the books we put in front of them do not always conform to the marketing aims. (para. 11)

If Hall and Slade (2011) were correct in assuming a limited impact for these political texts, what exactly do teenagers do with the content housed in these texts once they are consumed?

In general, utopian and dystopian "literature encourages people to view their society with a critical eye, sensitizing or predisposing them to political action" (Hintz \& Ostry, 2003, p. 7). It would follow that this would work on teenagers just as well as adults. Hintz and Ostry (2003) suggested that "exposure to these types of texts can lead young readers to see inequality in their own communities and countries” (p. 8). Although these texts may not automatically accomplish this on their own, these texts are often taught in educational settings and strategic instruction often increases their overall impact.

4 In this way, Titus more resembles the main characters of classic dystopias, such as D-503 in Zamyatin's (1926) We or Alex in Burgess's (1962) A Clockwork Orange. 
Glasglow (2001) encouraged utilizing dystopian novels in social justice units. She argued that "social justice education has the potential to prepare citizens who are sophisticated in their understanding of diversity and group interaction, able to critically evaluate social institutions, and committed to working democratically with diverse others" (p. 54). Similarly, Wolk (2009) stated that reading dystopian novels allows "students to question the world we have and envision a better world we could have" because these texts "offer unique opportunities to teach these habits of mind" (p. 668). These texts may be even more important to teach in this post-9/11 world because, as one secondary educator noted, it is more important than ever that "teachers select texts that will help students to critically examine the world and media representations of it" (Collins, Groenke, Rose-Shafer, \& Zenzano, 2006, p. 17). ${ }^{5}$ However, these texts can do more than just prompt students to examine the worldthey can be used as the catalyst to incite real action.

In her article, "Class on Fire: Using the Hunger Games Trilogy to Encourage Social Action," Simmons (2012) argued that Collins's dystopian series is an ideal tool to foster critical literacy and spark social action among teens. Simmons (2012) detailed how the trilogy can help students understand that violence directed toward children is not a fictional occurrence but a reality in this world, and that they can play a role in its abolition through social action projects. She provided lecture material to accompany the novels on issues such as national and global hunger, forced labor, the use of child warriors, and sex trafficking. Simmons (2012) discussed real social justice organizations that classes could become involved with, such as Loose Change to Loosen Chains, a student-led campaign designed to combat modern-day slavery. One possible student assignment she described involves students creating a multimedia project-one that would require students to design a logo, slogan, poster, and video to promote participation in this cause.

While the above discussion provides compelling justifications for using young adult dystopia within classroom settings, questions still remain: Do they work just as well outside such educational environments? How effective are these texts when they are consumed without the guidance of a teacher?

Although it seems logical to assume that the popularity of these novels implies that their teenage readers are interested in the social commentary they build upon, this is a hard assumption to verify. It could be that teens are just drawn to the fantastical settings, the romantic storylines, the coming-of-age themes, and the action-filled plots. However, if this were the case, one would expect to see other YA novels that include all of these aspects, topping them in sales and garnering the Hollywood movie deals. And this is not occurring as regularly. Quite obviously, there is something within these novels that speaks to this newest generation of readers. As discussed earlier, the most likely answer is that teenage readers are drawn to the way these texts repackage societal concerns from reality, displacing them into the safe comforts of fiction where they are addressed recurrently with more favorable results.

\footnotetext{
5 These texts need not be explicitly related to the terrorist attacks, but educators could easily locate texts that would facilitate a more direct engagement with 9/11 discourse. An issue of The English Journal (2006) published during the five year anniversary of the tragedy, houses a variety of teaching tools and strategies that educators could use to stimulate a critical conversation about the national event (Ruggieri, 2006, p. 80). Included in this list of resources are fictional texts like Forde's (2002) Hugo Award winning science fiction novella, In Spirit, which was written as a response to 9/11 (Collins et al., 2006, p. 17), as well as nonfiction texts like What Was it Like? Teaching History and Culture through Young Adult Literature (Rice, 2006); Whose Wars? Teaching about the Iraq War and the War on Terrorism (Rethinking Schools, 2005); and Stirring Up Justice: Writing and Reading to Change the World (Singer, 2006).
} 
It is not surprising that the decade following the 9/11 attacks produced many dystopian narratives. After all, "fiction writing in general rises out of times of upheaval because it imagines ways to cope with, understand or contain that volatility" (Dusinberre, 1987, p. 81). These narratives are important sites where the realities of a post-9/11 world are being worked out. Therefore, in consuming these texts, teenagers are likely working through fears lingering-unconsciously perhaps-years after the national trauma. Reading these books may not completely rewire the Millennial Generation, but it may find them contemplating some important societal problems-including those that led up to the 9/11 terrorist attacks, as well as other less tragic concerns such as the effects of reality television, superficial beauty standards, and over-reliance on social technology.

The popularity of these young adult novels does not invalidate the data that suggests that teenagers today are suffering from civic illiteracy and are not participating in the formal political process at desired rates. Although, to be fair, when the criticisms leveled at young adults are studied in greater cultural contexts, they often appear to be exaggerated. For example, data is often not relayed for other age groups, which might indicate that civic illiteracy, or disinterest in current political affairs, is more of a cultural phenomenon rather than an age-specific one. Also, these studies often fail to address the larger question of why this generation, or Americans more generally, are shying away from politics.

Nonetheless, taking these somewhat disturbing studies at face value, it does appear that young adults are, at least outwardly, politically disengaged. Despite their content, the mass consumption of these political narratives does not alter this fact. However, the popularity of these dystopian texts does suggest that the descriptor cast upon the age group is misleading. The very fact that this population is enthralled with these tales suggests that the classification of "apolitical," or at the very least "apathetic," is inaccurate. This literary trend indicates that while these young readers may be disheartened by contemporary politics and under-informed in current events, they are not uninterested in the social problems that underlie both. The success of these novels implies that teenagers are willing to entertain societal critiques-even ones that implicate themselves. Rather than being a problematic discrepancy, the "mismatch" between the reading interests of young adults and their direct political action suggests that young adults could easily be molded into more politically engaged citizens.

Perhaps this mismatch is not as great as it first seems. The fact that this post-9/11 reading trend aligns with recent increases in community service and voting among youth populations may indicate that a change is already underfoot (Sander \& Putman, 2010). Perhaps if their interests and concerns-as evidenced by their reading material-are addressed more regularly in the public sphere, and if they feel their voices will count in the democratic process, future research and poll data will reflect a very different political reality. Will reading young adult dystopias alone cause this political transformation? Not likely. And does the consumption of print texts often spark revolutionary change? No, but perhaps it is a start. Rather than predicting a bleak future for the young persons of today, this dystopian trend may very well be pointing toward a more positive future, at least in terms of political engagement.

\section{References}

Anderson, M. J. (1977). In keep of time. New York: Knopf.

Anderson, M. T. (2002). Feed. Cambridge, MA: Candlewick Press.

Askin, J. (2012). Occupy Wall Street as a pivoting startup: 'Generation why not' in a 'yeah but' world. Retrieved from http://www.huffingtonpost.com/jonathan-askin/occupy-wall-street-millennials_b_1069483.html 
Barnhurst, K. (1998). Politics in the fine meshes: Young citizens, power and media. Media Culture \& Society, 20(1), 201-18.

Bauerlein, M. (2009). The dumbest generation: How the digital age stupefies young Americans and jeopardizes our future, Or, don't trust anyone under 30. New York: Penguin.

Bertagna, J. (2011, June 5). Why are teenagers such avid readers of books about dystopias? The Scotsman. Retrieved from http://www.scotsman.com/news/books-why-are-teenagers-such-avid-readers-of-booksabout-dystopias-1-1667196.

Blasingame, J. (2003). An interview with M.T. (Tobin) Anderson. Journal of Adolescent and Adult Literacy, 47(1), 98-99.

Burgess, A. (1962). A clockwork orange. New York: W. W. Norton.

Captain, S. (2011, October 19). The demographics of Occupy Wall Street. Retrieved from http://www. fastcompany.com/1789018/demographics-occupy-wall-street

Collins, K., S. L. Groenke, M. J. Rose-Shafer, \& M. Zenzano. (2006). Teacher to teacher: What texts effectively raise issues related to 9/11 for secondary students? The English Journal, 96(2), 16-18.

Collins, S. (2008). The hunger games. New York: Scholastic.

Collins, S. (2009). Catching fire. New York: Scholastic.

Collins, S. (2010). Mocking jay. New York: Scholastic.

Condie, A. (2010). Matched. New York: Dutton Book.

Condie, A. (2011). Crossed. New York: Dutton Book.

Condie, A. (2012). Reached. New York: Dutton Book.

Cooper, C. (2001). Green boy. New York: Margaret K. McElderry Books.

Detora, L. (2006). Coming of age in suburbia: Sexual violence, consumer goods and identity in recent young adult novels. Modern Language Studies, 36(1), 24-35.

Devereaux, E. (2002, November 17). Feed. The New York Times Book Review, 47.

Doctorow, C. (2008). Little brother. New York: TOR Teen Book.

Doctorow, C. (2013). Homeland. New York: Tor Teen.

Dusinberre, J. (1987). Alice to the lighthouse: Children's books and radical experiments in art. New York: St. Martin's Press.

Forde, P. (2002). "In spirit." Analog Science Fiction and Fact. Retrieved from http://www.analogsf.com/ Nebulas03/Spirit.shtml.

Fulton, B. (2011, January 1). Romancing the future: Ally Condie's 'Matched.' Retrieved from http://www. sltrib.com/sltrib/entertainment/50949533-81/condie-book-books-matched.html.csp.

Gaudiosi, J. (2012). Hunger Games trilogy beats Harry Potter series to become all-time bestselling book series. Retrieved from http://www.forbes.com/sites/johngaudiosi/2012/08/17/hunger-games-trilogybeats-harry-potter-series-to-become-all-time-bestselling-book-series/

Gee, M. (1982). The halfmen of $O$. Auckland: Oxford University Press.

Glasglow, J. N. (2001). Teaching social justice through young adult literature. The English Journal, 90(6), $54-61$.

Goodnow, C. (2008, December 17). Profits of doom: Teen readers eat up post-apocalyptic tales. Retrieved from http://www.seattlepi.com/ae/books/article/Profits-of-doom-Teen-readers-eat-up-1295171.php

Granger, J. (2010, February 22). Unlocking 'The hunger games': The surface, moral, allegorical, and sublime meanings. Retrieved from http://www.hogwartsprofessor.com/unlocking-the-hunger-games-fourlayers-of-meaning.

Haddix, M. P. (2000). Among the hidden. New York: Simon \& Schuster.

Haddix, M. P. (2000). Turnabout. New York: Simon \& Schuster.

Hall, A. L., \& Slade, K. N. (2011, June 2). This is the way the world ends: A conversation between Kara N. Slade and Amy Laura Hall on domination and solidarity in young adult dystopias. The Other Journal: An Intersection of Theology and Culture. Retrieved from http://theotherjournal.com/2011/06/02/ this-is-the-way-the-world-ends-a-conversation-between-kara-n-slade-and-amy-laura-hall-on-dominationand-solidarity-in-young-adult-dystopias.

Hintz, C., \& Ostry, E. (2003). "Introduction.” In C. Hintz \& E. Ostry (Eds.), Utopian and dystopian writing for children and young adults, (pp. 1-20). New York: Routledge.

Hintz, C., Ostry, E., Sambell, K., \& Totaro, R. C. N. (2003). Annotated bibliography of utopian and dystopian writing for children and young adults. In C. Hintz \& E. Ostry (Eds.), utopian and dystopian writing for children and young adults (pp. 200-231). NY: Routledge.

Hoover, H. M. (1973). Children of morrow. New York: Four Winds Press.

Kelleher, V. (1995). Parkland. Ringwood: Viking Children's Books.

Kingkade, T. (2012, November). Youth vote 2012 turnout: Exit polls show greater share of electorate than in 2008. Retrieved from http://www.huffingtonpost.com/2012/11/07/youth-vote-2012-turnout-exitpolls_n_2086092.html

Lee, S. (2012, March). Updated figures for 'The Hunger Games' books more than 36.5M in print in the U.S. alone. Retrieved from http://shelf-life.ew.com/2012/03/28/hunger-games-updated-sales.

Lowry, L. (1993). The giver. New York: Bantam Doubleday Dell.

Lowry, L. (2000). Gathering blue. New York: Houghton Mifflin.

Macdonald, C. (1988). The lake at the end of the world. Ringwood: Viking Kestrel.

McNaughton, J. (2000). The secret under my skin. Toronto: HarperCollins.

Mindich, D. (2005). Tuned out: Why Americans under 40 don't follow the news. New York: Oxford UP.

Morris, W. M. (2011). Correlation, Top Tens and Ally Condie's Matched. Retrieved from http://www. motleyvision.org/2011/correlation-top-tens-ally-condie-matched. 
Nixon, W. (2011). Are zombies the guilty conscience of post-9/11 America? Retrieved from http://thesop. org/story/20111027/are-zombies-the-guilty-conscience-of-post911-america.html.

Parenteau, S. (1979). The Talking coffins of Cryo-City. New York: Elsevier/Nelson Books.

Park, R. (1986). My sister, Sif. Ringwood: Viking Kestrel.

Pew Research Center. (2007). The updated Pew IQ news quiz. Retrieved from http://pewresearch.org/ politicalquiz/

Pew Research Center. (2010). Politically apathetic Millennials. Retrieved from http://pewresearch.org/ daily-number/politically-apathetic-millenials/

Prince, A. (1986). The others. London: Methuen Children's.

Prinzi, T. (2010). The Hunger Games: Panem's Politics. Retrieved from http://thehogshead.org/the-hungergames-panems-politics-4426.

Putnam, R. D. (2001). Bowling alone: The collapse and revival of American community. New York: Simon and Schuster.

Rawls, K. (2012). What does our obsession with zombie stories tell us about our politics? Retrieved from http:// www.alternet.org/story/155783/what_does_our_obsession_with_zombie_stories_tell_us_about_our_politics.

Redfield, M. (2007). Virtual trauma: The idiom of 9/11. Diacritics, 37(1), 55-80.

Rethinking Schools, LTD. (2005). Whose wars? Teaching about the Iraq War and the War on Terrorism. Williston: Rethinking Schools.

Rhor, M. (2012). "Hunger Games” spurs dystopian reading trend. Retrieved from http://www.chron.com/ life/article/Hunger-Games-spurs-dystopian-reading-trend-3535441.php.

Rice, L. J. (2006). What was it like? Teaching history and culture through young adult literature. New York: Teachers College Press.

Richemont, E. (1990). The game. London: Walker Books.

Richer, S. (2012, November). A quick glance at the national youth vote. Retrieved from http://www.forbes. $\mathrm{com} /$ sites/stephenricher/2012/01/09/a-quick-glance-at-the-national-youth-vote.

Ruggieri, C. A. (2006). Teaching in a world of tragedy and terrorism. The English Journal, 96(2), 80-81.

Sander, T. H., \& Putnam, R. D. (2010). Still bowling alone?: The post-9/11 split. Journal of Democracy, 21(1), 9-15.

Sargent, P. (1980). Watchstar. New York: Pocket Books.

Schlee, A. (1979). The vandal. London: Macmillan Children's.

Scott, K. N., \& Dragoo, M. H. (2011). The baroque body: A social commentary on the role of body modification in Scott Westerfeld's Uglies trilogy. Retrieved from http://www.inter-disciplinary.net/ ci/cyber\% 20hub/visions/v3/scottdragoo\% 20paper.pdf

Simmons, A. M. (2012). Class on fire: Using the Hunger Games trilogy to encourage social action. The Journal of Adolescent and Adult Literacy, 56(1), 22-34.

Singer, J. (2006). Stirring up justice: Writing and reading to change the world. Portsmouth, NH: Heinneman.

Soloff, M. A. (2006). Undead America: Zombie films as metaphoric discourse of post-9/11 anxiety. Retrieved from http://etd.ohiolink.edu/view.cgi?acc_num=osu1209740275

Staig, L. (1989). The glimpses. London: Macmillan Children's.

Streiber, W. (1985). Wolf of shadows. New York: Knopf.

Thomas, F. (1988). Cityscape. London: Heinemann.

VanderMeer, J. (2008, August 14). Summer political fiction: From Jessica Z to Black Cloud 9. Retrieved from http://www.huffingtonpost.com/jeff-vandermeer/summer-political-fiction_b_118486.html

West, C., \& MacLean, K. (1979). DarkWing. New York: Antheneum.

Westall, R. (1983). Futuretrack 5. Harmondsworth: Kestrel.

Westerfeld, S. (2005). Uglies. New York: Simon Pulse.

Westerfeld, S. (2007). Extras. New York: Simon Pulse.

Wishon, J. (2012, October 9). Generation apathy? Millennial vote up in the air. Retrieved from http://www. cbn.com/cbnnews/politics/2012/October/Generation-Apathy-Millennial-Vote-Up-in-the-Air/

Wolk, S. (2009). Reading for a better world: Teaching social responsibility with young adult literature. Journal of Adolescent \& Adult Literacy, 52(8), 664-673.

Wyndam, J. (1955). The Chrysalids. London: Michael Joseph.

Zamyatin, Y. (1926). We. New York: E. P. Dutton \& Co., Inc.

Zipes, J. (2003). Foreword: Utopia, dystopia, and the quest for hope. In C. Hintz \& E. Ostry (Eds.), Utopian and dystopian writing for children and young adults, (pp. ix-2xi). New York: Routledge.

\section{触}

